\title{
腎疾患・糖尿病合併の 高血圧治療のポイント
}

\section{要 旨}

腎疾患と糖尿病は, 高血圧患者における脳心血管イベントの独立した重要 な危険因子である. 日本高血圧学会の高血圧治療ガイドライン 2014 (JSH2014) では蛋白尿を認める慢性腎臓病（chronic kidney disease : CKD）患者, 蛋白尿のないCKD患者, 糖尿病患者の降圧目標をそれぞれ 130/80 mmHg未満, 140/90 mmHg未満, 130/80 mmHg未満に設定して いる．イベント予防のためには厳格な降圧が必要である，その一方で，腎 疾患や糖尿病の合併例では動脈硬化が進行していることが多く, 過降圧に よる臓器の灌流不全に注意が必要である。

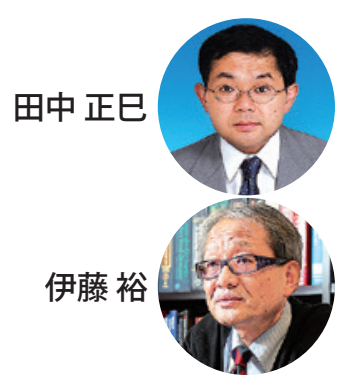

〔日内会誌 104：240～246，2015〕

Key words 慢性腎臓病，糖尿病，高血圧，蛋白尿/微量アルブミン尿，降圧目標

\section{はじめに}

糖尿病と高血圧は代表的な生活習慣病であ り，多くの腎疾患が生活習慣病を背景として発 症する。この3疾患は密接に関与し合い, 他の 疾患を発症・進展させるため, 自ずと合併頻度 は高くなる，全てが脳心血管疾患や死亡の危険 因子であり，これらの合併は国民の健康に対す る脅威である。本稿では合併の機序と意義, 合 併症例の特徵, 治療法を述べ, 腎疾患・糖尿病 合併高血圧患者の脳心血管イベントをどうした ら回避できるか考えてみたい.

\section{1. 腎疾患合併高血圧}

\section{1）腎疾患と高血圧}

高血圧と腎機能障害は, 相互に密接に関連し ている。高血圧は腎機能障害を発症させると同 時に，障害された腎機能をさらに低下させる。 本邦の健診データから, 高血圧が加齢, 糖尿病 とともに慢性腎藏病（chronic kidney disease： CKD）発症の主要な危険因子であることが示さ れている1). 糸球体濾過率 (glomerular filtration rate：GFR）は30歳代から加齢に伴い低下する が, 生理的な推算糸球体濾過率 (estimated GFR: eGFR）低下は $0.3 \mathrm{ml} /$ 分/年程度であるのに対し, 高血圧を合併するとその低下速度は $4 \sim 8 \mathrm{ml} /$ 
分/年程度に加速される. 一方, 腎実質性高血圧 に代表されるように, 腎機能障害は高血圧を引 き起こす。高血圧の有病率はGFRの低下につれ て直線的に増加する. 腎機能低下に伴い, 高率 に高血圧を合併するようになり, 腎不全の存在 は高血圧を難治化・重症化させる。すなわち, 高血圧と腎機能障害は, 一方の悪化が他方を悪 化させて未期腎不全（end-stage renal disease : ESRD）に至るという悪循環を形成している.

\section{2）CKD合併の意義}

\section{(1) CKD と心腎連関}

CKD発症の主要な危険因子として, 高血圧, 糖尿病, 肥満, 喫煙が知られている. CKD患者 は脳心血管イベントのリスクが高く, ESRDより も死亡のリスクの方が高い. CKD患者が心血管 イベントを起こしやすい理由として，体液調節 障害や内皮障害を引き起こす多くの因子が両者 の病態に共通して深く関わっていることが想定 されており，心腎連関と呼ばれている2). CKDが あると血圧上昇だけでなく, 夜間の降圧が消失 するなどの血圧日内変動異常も高頻度にみられ るようになり, CKD悪化, イベント発症率上昇 の一因となる. CKDの原疾患も重要で, 同程度 の腎機能低下では, 高血圧性腎硬化症や糖尿病 性腎症は慢性糸球体腎炎に比べて脳心血管イベ ントの発症率が高い.

\section{（2）CKD予防と早期発見の重要性}

蛋白尿はたとえ微量であっても脳心血管イベ ントの危険因子である. CKD患者の多くはESRD に至る前に, 脳心血管イベントで死亡する.し たがって, CKDはその予防と早期発見が極めて 重要である。透析導入の原因疾患としては糖尿 病腎症が他を圧倒して最多であり，CKD予防の ためには糖尿病対策が重要である。また, 加齢 や高血圧が原因で起こる腎硬化症や虚血性腎症 は, 今後高齢者人口の激増に伴い, 増加が予想 される. 減塩と適正体重の維持を中心とした高 血圧の予防も重要である. CKDの早期発見のた
め, 全ての高血圧患者で検尿とeGFRの算出を行 う。本邦の保険診療では尿アルブミンの測定は 糖尿病でのみ認められている。糖尿病合併例で は微量アルブミン尿を測定し, $30 \mathrm{mg} / \mathrm{gCr}$ 以上 であれば蛋白尿ありと判断する。糖尿病を合併 しない高血圧患者では尿蛋白定性を行う，尿蛋 白定性が（土）以上ならば，尿蛋白・尿クレア チニン值比 $(\mathrm{g} / \mathrm{gCr})$ を測定し, $0.15 \mathrm{~g} / \mathrm{gCr}$ 以上 で蛋白尿ありと判定する.

\section{（3）蛋白尿，アルブミン尿の意義}

蛋白尿, 微量アルブミン尿はESRDだけでな く, 脳心血管イベントの危険因子でもある. CKD において，GFRの低下と蛋白尿は独立した機序 により, ESRDや脳心血管イベントの危険因子と なる，尿蛋白排泄量が多く，GFRが低いほどそ のリスクは高まり, 両者が合併するとリスクは 相加的に高くなる ${ }^{3)}$. 一方, 尿蛋白の減少はESRD の発症抑制と強く関連する. 治療により尿蛋白 が減少するほどESRDや心血管イベントが抑制 され，この効果は血圧とは独立している。した がって, 尿蛋白量をできるだけ減少させること が重要であり, 可能であれば正常化を目指す. 尿蛋白減少のためには，十分に血圧を下げるこ と, レニンーアンジオテンシン (renin-angioten$\sin$ ：RA）系阻害薬を使うこと, 蛋白質摂取を制 限することが重要である. RA系阻害薬は用量依 存的に尿蛋白を減少させるため, 尿蛋白を指標 にしてRA系阻害薬を増量する。

\section{3）治療法}

\section{(1) 降圧目標}

海外のガイドラインはCKDの降圧目標を 140/90 mmHg未満に設定しているが, 高血圧治 療ガイドライン 2014(JSH2014) ${ }^{4}$ は異なる降 圧目標を設定している（表 1)。糖尿病を合併し ていれば, 蛋白尿/アルブミン尿の有無に関わら ず130/80 mmHg未満であるが，これについて は糖尿病合併高血圧の項で述べる。糖尿病がな い場合, 蛋白尿がなければ 140/90 mmHg未満 
表1 慢性腎臓病合併高血圧における降圧目標および第一選択薬（文献4より改变）

\begin{tabular}{|c|c|c|c|}
\hline & 降圧目標 & 第一選択薬 \\
\hline \multicolumn{2}{|l|}{ 糖尿病あり } & 130/80 mmHg未満 & RA系阻害薬 \\
\hline \multirow{2}{*}{ 糖尿病なし } & 蛋白尿なし & 140/90 mmHg未満 & RA系阻害薬，カルシウム拮抗薬，利尿薬 \\
\hline & 蛋白尿あり & 130/80 mmHg未満 & RA系阻害薬 \\
\hline
\end{tabular}

であるの対し，蛋白尿があれば 130/80 mmHg 未満と定めた。この根拠として, 日本人CKD患 者には脳卒中が多く, 脳卒中は厳格な降圧に よって予防できること，また蛋白尿の存在は腎 機能低下とは独立して, ESRDと脳心血管イベン トの重要な危険因子であることが挙げられる. ただし，高齢者や高度な動脈硬化が疑われる症 例では過度の降圧は避ける.CKD患者は発汗, 嘔吐，下痢，発熱などによる脱水を契機に過降 圧，急性腎障害を起こしやすいことにも注意が 必要である.

\section{（2）生活習慣修正}

食塩制限, 適正体重の維持, 禁煙および蛋白 質摂取制限を行う。食塩制限は $6 \mathrm{~g} /$ 日未満を推 奨し, $3 \mathrm{~g} /$ 日未満への制限は推奨しない. 蛋白 尿やESRDの発症には腹部肥満が関与しており, 肥満があれば減量すべきである。運動療法につ いては十分なエビデンスは存在しないが, 腎機 能に応じた指導を行う. GFR $60 \mathrm{ml} /$ 分 $/ 1.73 \mathrm{~m}^{2}$ 未満の透析患者を含むCKD患者においても, 運 動療法は高血圧を改善し, 心肺機能を高め, 生 活の質を向上させるが, 脳心血管イベント発症 や腎機能低下速度には影響を及ぼさないと考え られている。 また, GFR $60 \mathrm{ml} /$ 分 $/ 1.73 \mathrm{~m}^{2}$ 未満 のCKD患者では, 運動により有害事象がむしろ 増える危険性も指摘されている.

\section{（3）薬物療法}

血圧が目標降圧レベル以上の場合は生活習慣 の修正とともに, 直ちに降圧薬療法を開始す る。第一選択薬は糖尿病や蛋白尿の有無で異な
る（表 1)。糖尿病を合併する場合は蛋白尿の有 無に関わらず，他の薬剤に対する優越性が様久 な臨床試験で証明されているRA系阻害薬が第 一選択薬となる。一方，糖尿病を合併しない場 合は, 蛋白尿を認めればRA系阻害薬が第一選択 薬となる．蛋白尿を減少させる本薬剂は蛋白尿 陽性例, 特に蛋白尿が多い症例で藏器保護効果 を強く発揮する ${ }^{5)}$. 糖尿病も蛋白尿/アルブミン 尿も認めない場合は, RA系阻害薬の優越性は認 められて抢らず，RA系阻害薬，カルシウム怙抗 薬 (calcium channel blocker: CCB), 利尿薬の いずれもが第一選択薬になり得る. RA系阻害薬 は腎機能が悪くても使用可能であるが，GFR $30 \mathrm{ml} /$ 分 $/ 1.73 \mathrm{~m}^{2}$ 未満の進行したCKDや高齢者 CKDでは少量から使用し, eGFRや血清K值の変 化に注意する。 CCBの中にはシルニジピン，エ ホニジピン, ベニジピン, アゼルニジピンのよ うに優れた蛋白尿減少作用を有する薬剤もあ る。利尿薬を使用する場合, GFR $30 \mathrm{ml} /$ 分 $/ 1.73 \mathrm{~m}^{2}$ 以上の場合はサイアザイド系利尿 薬，それ未満の場合はループ利尿薬を用いる。

\section{2. 糖尿病合併高血圧}

\section{1) 糖尿病と高血圧}

本邦には糖尿病患者, CKD患者が約 1,000 万 人, 高血圧患者は約 4,300 万人存在する. 糖尿 病患者は高率に高血圧を合併する一方で, 高血 圧患者は高率に糖尿病を合併する。この理由と 
表2 改訂された糖尿病性腎症病期分類（糖尿病性腎症病期分類 2014）(文献7より改变)

\begin{tabular}{|c|c|c|}
\hline 病期 & 尿アルブミン值 $(\mathrm{mg} / \mathrm{gCr}) /$ 尿蛋白值 $(\mathrm{g} / \mathrm{gCr})$ & GFR (eGFR) (ml/分/1.73 m²) \\
\hline 第1期（腎症前期） & 正常アルブミン尿（<30） & \multirow{3}{*}{30 以上 } \\
\hline 第2期（早期腎症期） & 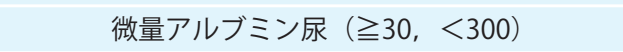 & \\
\hline 第3期（顕性腎症期） & 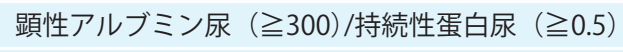 & \\
\hline 第4期（腎不全期） & 問わない & 30 未満 \\
\hline 第5期（透析療法期） & 透析療法中 & \\
\hline
\end{tabular}

して, 両者ともメタボリックシンドロームを構 成する疾患であり, 内臟脂肪蓄積を原因とした インスリン抵抗性という, 共通の機序を背景に していることが一因と考えられている。また， 両疾患とも代表的な生活習慣病であり, 食生活 の乱れや運動不足が両者を発症・悪化させてい るとも考えられる.

\section{2）糖尿病合併の意義}

\section{（1）大血管症のリスクとしての糖尿病}

心筋梗塞の既往のない糖尿病患者が虚血性心 疾患を初めて起こす確率と, 糖尿病のない心筋 梗塞既往者が再び虚血性心疾患を起こす確率が 同等であることが示されている6). すなわち, 糖尿病患者は糖尿病があるだけで二次予防に相 当する高リスクにさらされていることになる. JSH2014)では心血管病リスクの層別化におい て, 糖尿病をCKD同様, 独立した危険因子とし て重視している，糖尿病患者が大血管障害を発 症すると重篤になる可能性が高いため, 糖尿病 患者が高血圧を合併した場合には，大血管障害 の一次予防が極めて重要になる.

\section{（2）糖尿病合併高血圧の特徵}

血圧の正常な日内変動リズムが障害された non-dipperやriser，そして仮面高血圧が高頻度 で認められるが, これらは全て脳心血管イベン トの危険因子である。また, 糖尿病患者では食 塩感受性高血圧を多く認める. 動脈硬化の進行 や交感神経活性の克進も高頻度で認め, 高血圧 が難治性であることが稀ではない。さらに，糖
尿病罹病期間の長期化に伴い，糖尿病性神経障 害を合併すると, 起立性低血圧/高血圧の頻度が 高くなる.

\section{（3）糖尿病性腎症}

従来の糖尿病性腎症病期分類は尿アルブミン 排泄量に基づいてなされていたのに対し, 2007 年に登場したCKDステージ分類はGFRのみで分 類されていたため, 両者による分類が乘離する 症例が存在することが問題となった. 現在, 一 般臨床ではGFRの評価にeGFRが繁用されるよう になったこと，および2012年に新たにCKD重症 度分類が策定されたことを受けて，日本糖尿病 学会と日本腎臓学会の糖尿病性腎症合同委員会 により, 糖尿病性腎症の病期分類が改訂され た7)(表2).この改訂には, アルブミン尿とeGFR 低下の両者が独立した心血管イベントの重要な 危険因子であることが反映されている.

糖尿病とCKDが併存しても糖尿病性腎症とは 限らない点には注意が必要である。蛋白尿を認 めない場合，糖尿病罹病期間が短い（5年未満） 場合, 網膜症を認めない場合, 高度な血尿を伴 う場合, 腎臓の大きさに左右差がある場合, 腎 萎縮がみられる場合などは, 他の腎疾患の存在 を疑う必要がある。

糖尿病性腎症を合併すると，腎症が悪化する よりも高い確率で死亡すること，そして，その 主要な死因は大血管障害であることが示されて いる ${ }^{8)}$ (図 1). 糖尿病性腎症には, 厳格な血糖コ ントロール, 糸球体高血圧の是正, 脂質管理, 蛋白制限食, 減塩, 禁煙を中心とした集学的治 


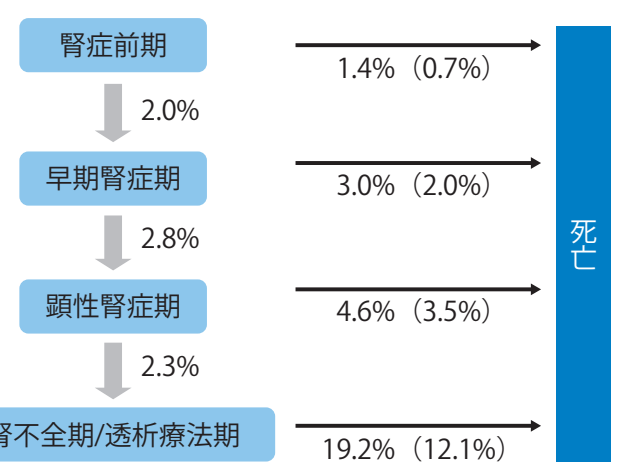

図 1 糖尿病性腎症の 1 年ごとの進行率と死亡率 (文献8より改变)

（ ）内は 1 年間の心血管イベントによる死亡率を 示す.

療が必要である. 可能な限り早期からの集学的 治療は糖尿病性腎症を寛解や退縮に導くことが でき, ESRDのみならず心血管イベント発症予防 も可能になる。糖尿病性腎症の寛解や退縮には RA系阻害薬が必要であることが本邦の臨床試 験9)で示されている.

\section{3）治療法}

\section{(1) 降圧目標}

糖尿病合併高血圧では脳心血管イベント抑制 のために厳格な降圧が必要である，海外では厳 格な降圧のメリットが認められないとの大規模 臨床試験の結果より, 糖尿病合併高血圧の降圧 目標が緩和されている。しかし，JSH20144)で は，本邦においては心筋梗塞に比べ脳卒中の発 症頻度が高いこと, 脳卒中は厳格な降圧で予防 が期待できることを根拠として, 従来の降圧目 標である 130/80 mmHg未満を緩和せずに堅持 することとした. 蛋白尿/アルブミン尿の有無に 関わらず，130/80 mmHg未満である.しかし， 動脈硬化性冠動脈疾患, 未梢動脈性疾患, 両側 頸動脈狭窄などを合併していて全身の高度な動 脈硬化が強く疑われる症例では, 厳格降圧に よって脳心血管イベントがむしろ増加するとの 報告がある。したがって, 過降圧に伴う臓器灌
流低下に対して十分な配慮が必要である。一過 性脳虚血発作, 狭心症, 急性腎障害の発症に注 意するとともに，家庭血圧など医療施設以外の 血圧測定を積極的に行うことが推奨される.

\section{（2）生活習慣修正}

血圧が 130/80 mmHg以上に上昇したら, 生 活習慣の修正と同時に降圧治療を開始する. 禁 煙, 6 g/日未満の減塩を指導する. 4〜 $5 \mathrm{~kg}$ の減 量で血圧は有意に下がることが知られており， 肥満症患者では特に, 生活習慣修正による降圧 が期待できる。血圧が 140/90 mmHg以上であ れば速やかに降圧薬を開始する。130～139/80 〜 89 mmHgの場合においては, 生活習慣の修正 で降圧が期待できる場合は, 生活習慣の修正に よる降圧を 3 力月間試み, 3 力月経過しても 130/80 mmHg未満を達成できなければ, 臨床的 には高血圧と判断して降圧薬の投与を開始す る. 生活習慣修正による降圧が困難と判断され れば, 速やかに降圧薬の投与を開始する (図2).

\section{(3) 薬物療法}

JSH2014では, 糖尿病合併高血圧治療の第一 選択薬としてACE阻害薬/ARBを推奨してい る ${ }^{4)}$. 本薬剂はアルブミン尿/蛋白尿の減少効果 に関して, そして, 糖尿病性腎症の進展抑制・ 寛解・退縮に関して豊富なエビデンスを有する ことがその根拠である。一方, アルブミン尿/蛋 白尿を合併しない糖尿病患者において, ACE阻 害薬/ARBと他の降圧薬との優劣を決める十分 なエビデンスは存在しない.しかし, 最近, ARB が正常アルブミン尿の2 型糖尿病患者におい て, 微量アルブミン尿発症を抑制することが示 された ${ }^{10)}$ 。糖尿病合併高血圧に対して，たとえ アルブミン尿がなくてもARBを優先的に投与す ることの新たな根拠として注目されている.さ らに, ACE阻害薬/ARBは優れたインスリン抵抗 性改善作用を有するため, 糖・脂質代謝に好影 響を与えることが期待される。

糖尿病合併高血圧は一般的に難治であり, 降 圧目標達成のためには 2〜3 剂以上の降圧薬の 


\section{降圧目標は130/80 mmHg未満}

\section{0/80 mmHg以上で治療を開始する}

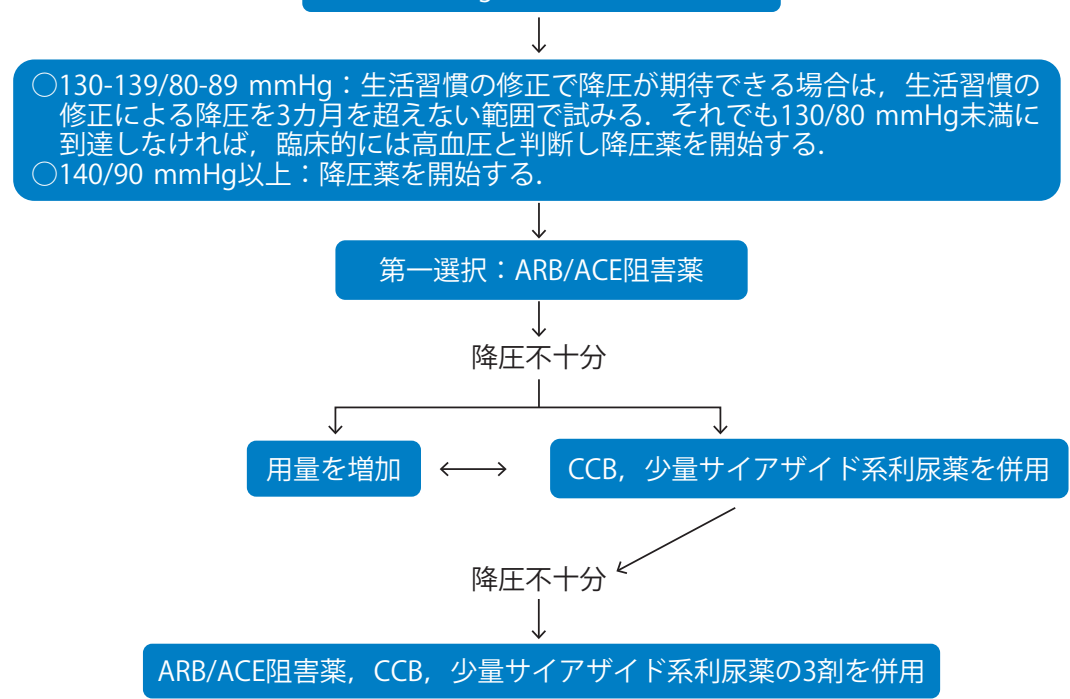

図2 糖尿病合併高血圧の治療方針 (文献4より改变)

CCB : カルシウム拮抗薬

併用が必要になることが多い。第一選択薬のみ で降圧不十分な場合の次の一手として, RA系阻 害薬の増量, 長時間作用型CCBの追加, 少量利 尿薬の追加のいずれもが推奨される（図2). そ れでも降圧不十分な場合には, RA系阻害薬, $\mathrm{CCB}$, 利尿薬の 3 剂を併用する. 労作性狭心症 合併や心筋梗塞既往例では，心保護作用を有す る $\beta$ 遮断薬も高血圧管理に使用可能である．利 尿薬を含む 3 剂以上の適正用量の降圧薬を用い ても降圧が困難な治療抵抗性高血圧が稀ではな いが，その場合は服薬アドヒアランスを確認す るとともに，原発性アルドステロン症などの二 次性高血圧の可能性を考慮する.

\section{おわりに}

高血圧患者においてCKD, 糖尿病はいずれも， 独立した脳心血管イベントや死亡の重要な危険 因子であり，イベント予防のためには厳格な降 圧が必須である. 生活習慣修正を徹底したうえ での適切な降圧薬療法により降圧目標が達成さ れ, 健康寿命の延伸, 生命予後の改善, QOL （quality of life）低下の抑制が実現されることを 期待する.

著者のCOI (conflicts of interest) 開示 : 田中正巳 ; 寄付 講座 (中外製薬)，伊藤 裕；報酬（ニプロ），講演料 (MSD，武田薬品工業)，寄付金（アステラス製薬，アス トラゼネカ，MSD，協和発酵キリン，サノフィ，第一三 共，武田薬品工業，田辺三菱製薬，帝人ファーマ，日本 イーライリリー) 
1) Yamagata K, et al : Risk factors for chronic kidney disease in a community-based population : a 10-year follow-up study. Kidney Int 71 : 159-166, 2007.

2）日本腎臓学会：CKD診療ガイド2012. 日本腎臓学会編. 東京医学社, 東京, 2012.

3) Irie $\mathrm{F}$, et al : The relationships of proteinuria, serum creatinine, glomerular filtration rate with cardiovascular disease mortality in Japanese general population. Kidney Int 69 : 1264-1271, 2006.

4）日本高血圧学会高血圧治療ガイドライン作成委員会：高血圧治療ガイドライン 2014 . 日本高血圧学会編. ライフサ イエンス出版, 東京, 2014 .

5) Wright JT Jr, et al : Effect of blood pressure lowering and antihypertensive drug class on progression of hypertensive kidney disease : results from the AASK trial. JAMA $288: 2421-2431,2002$.

6) Haffner SM, et al : Mortality from coronary heart disease in subjects with type 2 diabetes and in nondiabetic subjects with and without prior myocardial infarction. N Engl J Med 339 : 229-234, 1998.

7）糖尿病性腎症合同委員会：糖尿病性腎症病期分類20140策定（糖尿病性腎症病期分類改訂）について. 糖尿病 57 ： 529-534, 2014.

8) Adler AI, et al : Development and progression of nephropathy in type 2 diabetes : The United Kingdom Prospective Diabetes Study (UKPDS 64). Kidney Int 63 : 225-232, 2003.

9) Makino $\mathrm{H}$, et al : Prevention of transition from incipient to overt nephropathy with telmisartan in patients with type 2 diabetes. Diabetes Care 30 : 1577-1578, 2007.

10) Haller $\mathrm{H}$, et al : Olmesartan for the delay or prevention of microalbuminuria in type 2 diabetes. N Engl J Med 364 : 907-917, 2011. 